\title{
Penerapan Metode Pembelajaran Sugesti-Imajinasi Untuk Meningkatkan Minat Dan Hasil Belajar Menulis Cerpen Siswa
}

\author{
Ni Nengah Ariati \\ SMP Negeri 3 Selat \\ ariatinegah@gmail.com
}

DOI : $10.37329 /$ cetta.v3i1.409

\begin{tabular}{l}
\hline Keywords: \\
\hline Suggestion- \\
Imagination \\
Learning Method, \\
Interest, and \\
Learning \\
Outcomes. \\
\hline
\end{tabular}

\begin{abstract}
This study aims to increase the interest and learning outcomes of short story writing students of the IX-B class of SMP Negeri 3 Selat in the first semester of the 2018/2019 academic year. The subjects in this study were students of class IX-B, SMP Negeri 3 Selat, amounting to 31 people, consisting of 13 male students and 18 female students in the first semester of the 2018/2019 academic year. This study uses a class action research design through two stages. Data about students' interest in learning was collected by observation sheets, and short story learning outcomes were collected by the test method. Both types of data are analyzed by quantitative descriptive methods. The results of this study indicate that the application of the Suggestion-Imagination learning method can increase interest in learning and learning outcomes in short story writing for Class IX-B students of SMP Negeri 3 Selat in the first semester of the 2018/2019 academic year. with an average of 65.16 and completeness $51.61 \%$ in the first stage, being an average of students' learning interest of 83.55 and a completeness level of $93.55 \%$ in the second stage. While student learning outcomes also increased from an average of 68.87 in the first stage and the classical completeness rate of $51.61 \%$, increased to an average of 75.48 in the second stage and a mastery level of $77.42 \%$. Based on these results it is recommended; (1) utilize the Suggestion-Imagination method to increase interest and learning outcomes of short story writing; (2) make the results of this study a consideration in developing learning methods; (4) try this method on other material, or even on other subjects.
\end{abstract}

\begin{tabular}{lll}
\hline Kata Kunci: & Abstrak \\
\cline { 1 - 1 } $\begin{array}{l}\text { Hasil Belajar, } \\
\text { Minat, Sugesti- }\end{array}$ & $\begin{array}{l}\text { Penelitian ini bertujuan untuk meningkatkan meningkatkan } \\
\text { Imajinasi. }\end{array}$ & $\begin{array}{l}\text { Negeri } 3 \text { Selat semester I tahun pelajaran 2018/2019. Subjek } \\
\text { dalam penelitian ini adalah siswa kelas IX-B SMP Negeri 3 Selat }\end{array}$ \\
\hline & yang berjumlah 31 orang, terdiri dari 13 orang siswa laki dan 18 \\
& siswa prempuan pada semester I tahun pelajaran 2018/2019. \\
& Penelitian ini menggunakan rancangan penelitian tindakan kelas \\
& melalui dua siklus. Data tentang minat belajar siswa \\
\hline
\end{tabular}


dikumpulkan dengan lembar observasi, dan data hasil belajar menulis cerpen dikumpulkan dengan metode tes. Kedua jenis data yang dianalisis dengan metode deskriptif kuantitatif. Hasil penelitian ini menunjukkan bahwa penerapan metode pembelajaran Sugesti-Imajinasi dapat meningkatkan minat belajar dan hasil belajar menulis cerpen siswa Kelas IX-B SMP Negeri 3 Selat semester I tahun pelajaran 2018/2019, yaitu pada observasi awal minat belajar siswa rendah, minat belajar siswa meningkat dengan rata-rata 65,16 dan ketuntasan $51,61 \%$ pada siklus I, menjadi rata-rata minat belajar siswa sebesar 83,55 dan tingkat ketuntasan 93,55\% pada siklus II. Sedangkan hasil belajar siswa juga meningkat dari rata-rata 68,87 pada siklus I dan tingkat ketuntasan klasikal sebesar 51,61\%, meningkat menjadi rata-rata 75,48 pada siklus II dan tingkat ketuntasan 77,42 \%. Berdasarkan hasil tersebut disarankan; (1) memanfaatkan metode Sugesti-Imajinasi untuk meningkatkan minat dan hasil belajar menulis cerpen; (2) menjadikan hasil penelitian ini sebagai pertimbangan dalam mengembangkan metode pembelajaran; (4) mencobakan metode ini pada pada materi lain, atau bahkan pada mata pelajaran yang lain.

\section{Pendahuluan}

Pembelajaran menulis cerpen penting untuk diajarkan di sekolah-sekolah khususnya di tingkat SMP sederajat, mengingat pembelajaran itu dianggap banyak memberi manfaat bagi kehidupan nyata para siswa. Cerpen dapat dijadikan sebagai wadah yang positif bagi siswa untuk mencurahkan pengalaman, emosi, dan isi hati (Burhan, 2011). Pembelajaran menulis cerpen juga sejalan tujuan pembelajaran Bahasa dan Sastra Indonesia di antaranya untuk mempertajam perasaan, penalaran, daya imajinasi, kepekaan terhadap masyarakat, budaya, dan lingkungan hidup pembelajar. Namun faktanya keterampilan menulis cerpen siswa kelas IX SMP Negeri 3 Selat pada semester I tahun pelajaran sebelumnya (Tahun Pelajaran 2017/2018) masih di bawah kriteria ketuntasan yang ditetapkan yang ditetapkan, seperti tabel berikut ini.

Tabel 1 Rata-rata Nilai Menulis Cerpen Siswa Kelas IX

SMP Negeri 3 Selat Tahun Pelajaran 2017/2018.

\begin{tabular}{|c|c|c|l|}
\hline No. & Kelas & Rata-Rata Nilai & \multicolumn{1}{|c|}{$\begin{array}{c}\text { Keterangan } \\
(\text { KKM 70) }\end{array}$} \\
\hline 1. & IX-A & 70,25 & Tercapai \\
\hline 2. & IX-B & 65,52 & Belum tercapai \\
\hline 3. & IX-C & 66,45 & Belum tercapai \\
\hline
\end{tabular}




\begin{tabular}{|c|c|c|l|}
\hline 4. & IX-D & 64,45 & Belum tercapai \\
\hline 5. & IX-E & 65,05 & Belum tercapai \\
\hline \multicolumn{2}{|c|}{ Rata-Rata } & 65,47 & Belum tercapai \\
\hline
\end{tabular}

(Sumber: Daftar Nilai Guru Bahasa Indonesia Kelas IX Tahun Pelajaran 2017/2018).

Kurikulum SMP Negeri 3 Selat tahun pelajaran 2018/2019 masih menetapkan KKM untuk standar kompetensi SK 8. Mengungkapkan kembali pikiran, perasaan, dan pengalaman dalam cerita pendek; KD. 8.1 Menulis kembali dengan kalimat sendiri cerita pendek yang pernah dibaca, dan; KD. 8.2 Menulis cerita pendek bertolak dari peristiwa yang pernah dialami adalah 70 , dengan ketuntasan klasikal $75 \% \geq$ siswa meraih nilai $70 \geq$. Pembelajaran menulis cerpen dirasa berat oleh siswa. Hal itu rasanya wajar karena pembelajaran menulis cerpen merupakan pembelajaran apresiasi sastra yang tingkatannya paling tinggi, sejalan dengan pendapat Marsini (2009) yang menyatakan bahwa pembelajaran menulis cerpen merupakan salah satu keterampilan berbahasa yang proses pembelajaran dan hasil belajarnya paling banyak dikeluhkan para guru yang membidangi mata pelajaran tersebut (Burhan, 2011).

Berdasarkan sebaran angket minat menulis cerpen pada awal semester I tahun pelajaran 2018/2019 pada siswa kelas IX-B SMP Negeri 3 Selat, proses pembelajaran menulis cerpen merupakan proses pembelajaran yang paling kurang diminati siswa. Hasil rekapitulasi terungkap juga bahwa yang mana minat belajar menulis cerpen siswa masih rendah. Hal ini terlihat dari 31 orang siswa di kelas ini dari hasil angket awal, siswa pada umumnya jarang (tidak pernah) menulis cerpen. Hanya 6,45\% siswa yang mengaku pernah menulis cerpen, walaupun $100 \%$ siswa mengaku pernah diajak praktik menulis cerpen oleh gurunya. Penyebabnya adalah sebagaian besar siswa (80,65\%) merasa tidak senang. Alasan lainya yaitu siswa merasa malu, takut, dan bingung karena merasa wawasannya kurang, kurang percaya diri, gugup sulit menentukan gagasan, dan berbagai alasan lainya. Hal itu menyebabkan seluruh siswa menganggap perlunya metode pembelajaran yang mendukung keberhasilan menulis cerpen.

Kondisi yang demikian tentu tidak bisa dibiarkan. Guru memiliki kewajiban untuk memperbaiki kualitas proses dan hasil pembelajaran. Harus ada upaya untuk menciptakan sebuah proses pembelajaran menulis cerpen yang mampu mendongkrak minat dan hasil belajar siswa. Pentingnya mengatasi permasalahan rendahnya minat dan hasil belajar dalam pembelajaran menulis cerpen ini, disamping karena adanya kecenderungan semakin menurunnya kemampuan siswa dalam menulis cerpen, juga 
dikarenakan pertimbangan bahwa menulis cerpen merupakan salah satu kegiatan apresiasi sastra yang dapat dimanfaatkan oleh siswa sebagai wahana untuk menyalurkan ide, emosi, imajinasi, pengalaman dan bakatnya dalam menulis. Kegiatan mengapresiasi sastra berkaitan erat dengan pelatihan mempertajam perasaan, penalaran, daya imajinasi, kepekaan terhadap masyarakat, budaya, dan lingkungan hidup (Burhan, 2011). Melalui kegiatan menulis cerpen siswa akan memperoleh berbagai macam keuntungan, baik yang menyangkut pengetahuan maupun yang menyangkut keterampilan (berbahasa) dan berbagai kapasitas yang berkaitan dengan emosi yang dibutuhkan oleh manusia atau individu yang sedang berkembang (Wardani, 1981).

Untuk itu metode alternatif untuk mengembangkan pembelajaran sangat diperlukan, sebab pemegang kunci utama untuk memperbaiki kondisi ini tentu saja guru. Guru harus berani melakukan inovasi pembelajaran. Guru harus berupaya untuk menciptakan pembelajaran menulis cerpen yang sesuai dengan karakteristik cerpen. Cerpen adalah sebuah karya seni yaitu seni bahasa yang mengungkapkan pikiran dan perasaan penyair secara imajinatif dan disusun dengan mengkonsentrasikan semua kekuatan bahasa dengan pengkonsentrasian struktur fisik dan struktur batinnya (Burhan, 2011). Karakteristik penciptaan cerpen yang lebih banyak dipengaruhi oleh daya khayal atau imajinasi penulis dapat dimanfaatkan sebagai bahan pertimbangan bagaimana menciptakan suasana pembelajaran menulis cerpen yang mampu memancing, menggali, dan mengoptimalkan daya khayal atau imajinasi siswa.

Dengan menempatkan pembelajaran menulis cerpen pada karakteristik asal penciptaannya yang lebih banyak dipengaruhi daya khayal atau imajinasi penulisnya, misalnya dengan menciptakan suasana pembelajaran menulis cerpen yang mampu menggali daya khayal atau imajinasi siswa, tentu akan berdampak pada pembelajaran yang lebih menarik hati siswa dan memudahkan siswa mendapatkan inspirasi dalam menulis cerpen. Pembelajaran menulis cerpen yang dilakukan dalam bentuk pembelajaran yang mengaitkan karakteristik cerpen tersebut dimaksudkan untuk mendekatkan kegiatan menulis cerpen dengan siswa. Pembelajaran sebagai upaya sistematik dan sistemik untuk menciptakan lingkungan belajar yang potensial untuk menginisiasi, memfasilitasi dan meningkatkan proses belajar yang bermuara pada berkembangnya potensi individu sebagai peserta didik (Burhan, 2011). 
Berdasarkan permasalahan yang ditemukan dalam pembelajaran menulis di kelas IX-B SMP Negeri 3 selat semester I tahun pelajaran 2018/2019 dan karakteristik cerpen, maka metode pembelajaran yang dirasa tepat yaitu metode Sugesti-Imajiansi. Pembelajaran menulis dengan menerapkan metode Sugesti-Imajinasi dapat dijadikan sebagai salah satu alternatif pembelajaran yang mampu menciptakan suasana pembelajaran yang penuh dengan imajinasi yang sangat dibutuhkan oleh siswa dalam menggali inspirasi dan bahan penulisan cerpen.

Metode Sugesti-Imajinasi adalah sebuah metode yang berupaya untuk menciptakan suasana "sugestif". Pada prinsipnya, metode ini digunakan dengan cara memberi sugesti untuk merangsang daya imajinasi siswa (Trimantara, 2005). Metode Sugesti-Imajinasi dalam pembelajaran menulis cerpen adalah sebuah metode pembelajaran menulis cerpen dengan cara memberikan sugesti akan merangsang imajinasi siswa (Haryadi, 2011). Dalam Kamus Besar Bahasa Indonesia sugesti bermakna pengaruh dsb, yang dapat menggerakkan hati orang dsb; dorongan, sedangkan imajinasi bermakna 1 daya pikir untuk membayangkan (dl angan-angan) atau menciptakan gambar (lukisan, karangan, dsb) kejadian berdasarkan kenyataan atau pengalaman seseorang; 2 khayalan. Dalam hal ini, peristiwa berkesan yang pernah dialami siswa digunakan sebagai pencipta suasana sugestif, stimulus, dan sekaligus menjadi jembatan bagi siswa untuk membayangkan atau menciptakan gambaran dan kejadian sebenarnya (Depdiknas, 2008).

Respon yang diharapkan muncul dari para siswa berupa kemampuan melihat gambaran-gambaran kejadian tersebut dengan imajinasi-imajinasi dan logika yang dimiliki lalu mengungkapkan kembali dengan menggunakan simbol-simbol verbal Berdasarkan latar belakang di atas, rumusan masalah penelitian ini adalah sebagai berikut. 1) Apakah penerapan metode Sugesti-Imajinasi dapat meningkatkan minat belajar menulis cerpen siswa kelas IX-B SMP Negeri 3 Selat semester I tahun pelajaran 2018/2019?. 2) Apakah penerapan metode Sugesti-Imajinasi dapat meningkatkan hasil belajar menulis cerpen siswa kelas IX-B SMP Negeri 3 Selat semester I tahun pelajaran 2018/2019?. Sesuai dengan rumusan masalah di atas maka tujuan penelitian ini adalah seperti berikut ini. 1) Untuk meningkatkan minat belajar menulis cerpen siswa kelas IX-B SMP Negeri 3 Selat semester I tahun pelajaran 2018/2019 melalui penerapan metode Sugesti-Imajinasi. 2) Untuk meningkatkan hasil belajar menulis cerpen siswa kelas IX-B SMP Negeri 3 Selat semester I tahun pelajaran 2018/2019 melalui penerapan metode 
Sugesti-Imajinasi. Adapun hipotesis tindakan penelitian ini sebagai berikut. 1) Penerapan metode Sugesti-Imajinasi dapat meningkatkan minat dalam pembelajaran menulis cerpen siswa kelas IX-B SMP Negeri 3 Selat semester I tahun pelajaran 2018/2019. 2) Penerapan metode Sugesti-Imajinasi dapat meningkatkan hasil belajar dalam pembelajaran menulis cerpen siswa kelas IX-B SMP Negeri 3 Selat semester I tahun pelajaran 2018/2019.

\section{Metode}

Penelitian ini dilakukan pada siswa kelas IX-B SMP Negeri 3 Selat, selama \pm 6 bulan, mulai bulan Juli sampai Desember 2018. Subjek penelitian berjumlah 31 orang siswa, yaitu 13 orang siswa laki dan 18 orang siswa perempuan. Observasi awal terhadap masalah minat belajar menulis cerpen siswa kelas IX-B, serta identifikasi hasil belajar menulis cerpen siswa kelas IX tahun pelajaran sebelumnya (2017/2018) dilakukan pada minggu ke-4 bulan Juli tahun 2018. Rancangan penelitian ini didesain sesuai dengan standar kompetensi dan kompetensi dasar untuk menulis cerita pendek di kelas IX semester I, seperti gambar berikut.

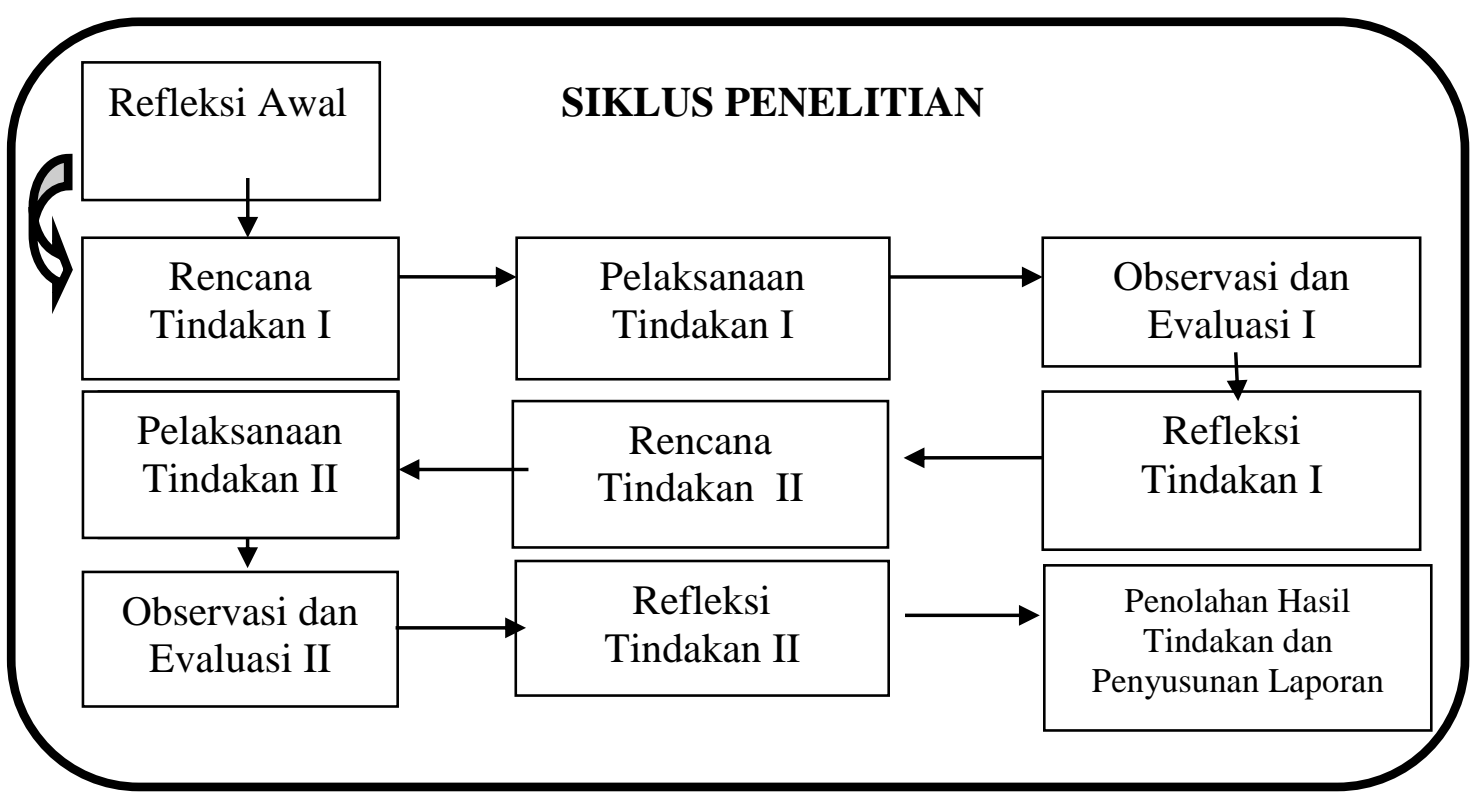

Pengumpulan data dalam penelitian ini secara ringkas dapat dilihat pada tabel berikut.

Tabel 2 Teknik dan Instrumen Pengumpulan Data.

\begin{tabular}{|l|lr|c|l|}
\hline No & Data & Teknik Pengumpulan Data & Instrumen \\
\hline 1 & $\begin{array}{l}\text { Minat siswa terhadap } \\
\text { pelajaran }\end{array}$ & menulis cerpen & -Nontes & $\begin{array}{l}\text { Lembar } \\
\text { observasi }\end{array}$ \\
\hline
\end{tabular}




\begin{tabular}{|l|l|c|l|}
\hline 2 & Hasil Belajar siswa dalam & -Tes & -Tes menulis \\
pelajaran menulis cerpen & & cerpen \\
\hline
\end{tabular}

Data minat menulis teks deskripsi siswa dikumpulkan dengan lembar observasi.

Penyusunan lembar observasi ini diadaptasi dari pengertian minat dari (Crow, 1989). Berdasarkan teori-teori ini diperoleh indikator-indikator untuk mengukur minat belajar siswa terhadap pelajaran menulis cerpen sebagai berikut. Indikator-indikator itu, adalah: (1) perhatian, (2) dorongan, dan (3) ketekunan. Pedoman ini disusun dengan menggunakan skala model Likert yang terdiri atas lima pilihan jawaban yang bersifat gradasi yaitu: sangat baik, baik, cukup, kurang, dan sangat kurang. Sifat jawaban pertanyaan ini ada dua macam yaitu positif dan negatif. Pemberian skor untuk masingmasing butir adalah mulai dari lima hingga satu. Pemberian skor terhadap butir pernyataan dapat disajikan pada tabel berikut.

Tabel 3 Kriteria Penskoran Pedoman Observasi.

\begin{tabular}{|l|l|l|}
\hline Pendapat & Nilai Positif & Nilai Negatif \\
\hline Sangat baik & 5 & 1 \\
\hline Baik & 4 & 2 \\
\hline Cukup & 3 & 3 \\
\hline Kurang & 2 & 4 \\
\hline Sangat kurang & 1 & 5 \\
\hline
\end{tabular}

(Skala Model Likert)

Untuk menghitung hasil observasi minat siswa digunakan rumus sebagai berikut.

$\mathrm{X}=\underline{\mathrm{O}-1+\mathrm{O}-2+\mathrm{O}-\mathrm{ke}-\mathrm{N}}$

$\Sigma \mathrm{O}$

Keterangan:

$\mathrm{X}=$ Skor mentah rata-rata;

O-1 = Skor mentah hasil observasi 1 ;

O-2 = Skor mentah hasil observasi 2;

O-ke-N = Skor mentah hasil observasi ke berikutnya;

$\Sigma \mathrm{O}=$ Jumlah observasi. 
Data yang sudah diperoleh pada lembar observasi akan dimasukkan pada pedoman observasi untuk memperoleh keseluruhan skor dari setiap siswa. Skor yang diperoleh berupa skor mentah, kemudian akan dirubah menjadi skor standar. dipergunakan rumus sebagai berikut.

$\mathrm{P} \frac{\mathrm{X}}{\mathrm{SMI}} \times 100$

Keterangan

$\mathrm{P}=$ Persentil

$\mathrm{X}=$ Skor yang dicapai

SMI = Skor maksimum ideal (Nurkancana, 1992).

Kategori minat siswa dalam menulis cerpen dengan metode Sugesti-Imajinasi digunakan adalah kriteria yang lazim digunakan di dalam tabel di bawah ini.

Tabel 4 Kategori Minat Menulis Siswa.

\begin{tabular}{|l|l|}
\hline KATEGORI & PRESENTASE (\%) \\
\hline Sangat Tinggi & $81-100$ \\
\hline Tinggi & $61-80$ \\
\hline Sedang & $41-60$ \\
\hline Rendah & $0-40$ \\
\hline
\end{tabular}

Data hasil belajar menulis cerpen diolah sebagai berikut: (1) mengubah skor mentah menjadi skor standar, (2) mencari skor rata-rata, (3) menentukan daya serap (DS) siswa, dan (4) menentukan ketuntasan klasikal (KK).

\section{Hasil dan Pembahasan}

\section{Hasil Penelitian}

\section{a. Hasil Analisis Minat Belajar Siswa Siklus I dan Siklus II}

Pada penelitian ini metode observasi digunakan untuk menganalisis minat siswa dalam proses pembelajaran di dalam kelas. Data yang diperoleh adalah hasil dari pengolahan data dalam observasi minat siswa. Data tersebut dianalisis dengan cara deskriptif kuantitatif. Data minat menulis teks deskripsi siswa dikumpulkan dengan lembar observasi. Penyusunan lembar observasi ini diadaptasi dari pengertian minat dari (Crow, 1989). Berdasarkan teori-teori ini diperoleh indikator-indikator untuk mengukur minat belajar siswa terhadap pelajaran menulis cerpen sebagai berikut. Indikatorindikator itu, adalah: (1) perhatian, (2) dorongan, dan (3) ketekunan. 
Pedoman ini disusun dengan menggunakan skala model Likert yang terdiri atas lima pilihan jawaban yang bersifat gradasi, yaitu: sangat baik, baik, cukup, kurang, dan sangat kurang. Sifat jawaban pertanyaan ini ada dua macam yaitu positif dan negatif. Pemberian skor untuk masing-masing butir adalah mulai dari lima hingga satu. Pemberian skor 5 apabila minat belajar siswa sangat baik, skor 4 apabila baik, skor 3 cukup, skor 2 kurang, dan skor 1 bila minat siswa sangat kurang. Kegiatan ini akan memberi informasi terhadap minat belajar siswa. Observasi dilakukan setiap pertemuan, untuk mendapatkan jumlah skor hasil observasi $(\mathrm{O})$ dari setiap pertemuan. Selanjutnya hasil observasi (O-1+O-2) dirata-ratakan, menjadi skor mentah minat belajar $(\mathrm{X})$.

Hasil berupa skor mentah akan diubah menjadi skor standar. Hasil penyekoran dalam pengolahan data di atas masih berupa skor mentah, skor tersebut harus diubah kedalam bentuk skor standar sehingga di dapat hasil yang riil. Mengubah skor mentah menjadi skor standar digunakan rumus berikut ini.

$\mathrm{P}=$

$$
\frac{X}{S M I} \times 100
$$

Berdasarkan analisis, minat belajar siswa siswa Kelas IX-B SMP Negeri 3 Selat semester I tahun pelajaran 2018/2019 dapat dilihat pada tabel berikut ini.

Tabel 5 Perbandingan Minat Belajar Siswa Kelas IX-B SMP Negeri 3 Selat

Semester I Tahun Pelajaran 2018/2019 Siklus I dan Siklus II.

\begin{tabular}{|c|l|c|c|c|}
\hline \multirow{2}{*}{ No. } & \multicolumn{1}{|c|}{ Aspek } & \multicolumn{2}{|c|}{ Minat Belajar Siswa } & \multirow{2}{*}{ Keterangan } \\
\cline { 3 - 4 } & & Siklus I & Siklus II & \\
\hline 1. & Jumlah & 2020 & 2590 & Meningkat \\
\hline 2. & Rata-Rata & 65,16 & 85,55 & Meningkat \\
\hline 3. & Ketuntasan Klasikal & $51,61 \%$ & $93,55 \%$ & Meningkat \\
\hline
\end{tabular}

Untuk lebih memperjelas perbandingan minat belajar siswa Kelas IX-B SMP Negeri 3 Selat semester I tahun pelajaran 2018/2019, disajikan dalam bentuk grafik perbandingan minat belajar siswa pada siklus I dan siklus II dapat dilihat seperti grafik berikut ini. 


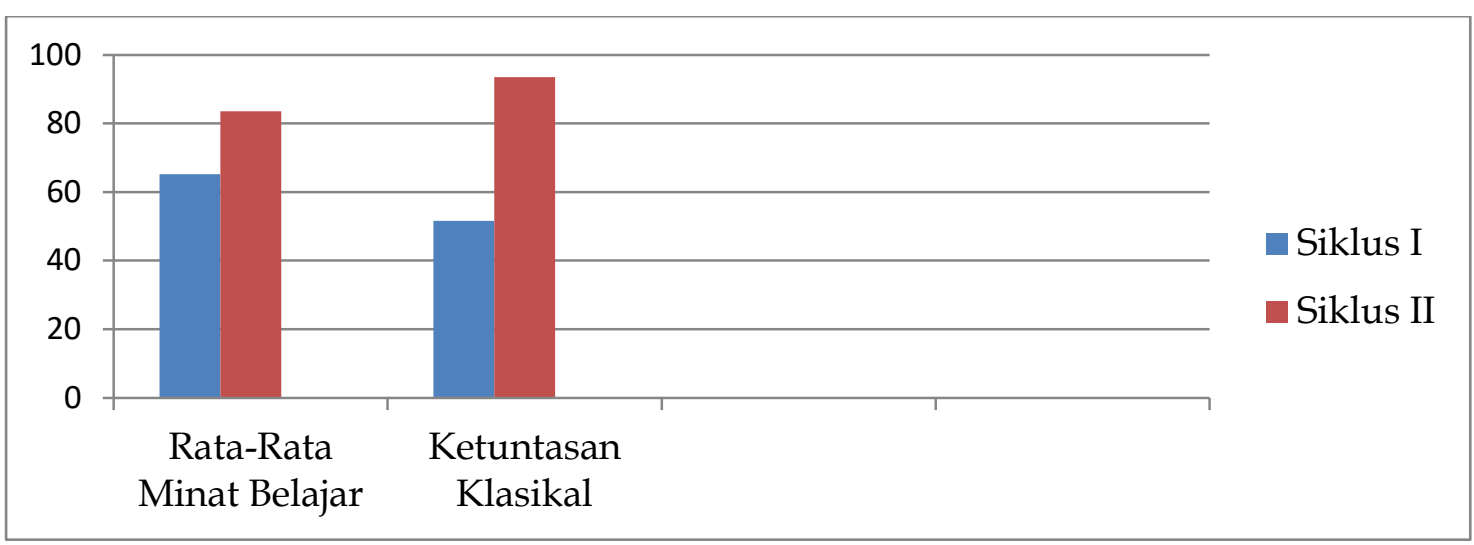

Gambar 2 Grafik Perbandingan Minat Belajar Siswa Kelas IX-B SMP Negeri 3 Selat

Semester I Tahun Pelajaran 2018/2019 pada Siklus I dan Siklus II

\section{b. Hasil Analisis Belajar Siklus I dan Siklus II}

Dari pelaksanaan tindakan siklus I dan siklus II, data hasil penelitian tentang hasil belajar menulis cerpen siswa yang berupa skor mentah diubah menjadi skor standar dengan rumus:

$\mathrm{P}=$

$$
\frac{X}{S M I} \times 100
$$

Mengingat 5 aspek yang dipakai mengukur hasil belajar siswa di dalam penelitian ini dengan bobot maksimal 20 tiap aspek, maka SMI-nya adalah =100. Berdasarkan rumusan tersebut skor standar dari masing-masing penguasaan siswa dapat dihitung seperti tabel berikut.

Tabel 6 Perbandingan Hasil Belajar Siswa Kelas IX-B SMP Negeri 3 Selat Semester I Tahun Pelajaran 2018/2019.

\begin{tabular}{|c|c|c|c|c|}
\hline \multirow[t]{2}{*}{ No. } & \multirow[t]{2}{*}{ Aspek } & \multicolumn{2}{|c|}{ Hasil Belajar Siswa } & \multirow[t]{2}{*}{ Keterangan } \\
\hline & & Siklus I & Siklus II & \\
\hline 1. & Jumlah & 2005 & 2200 & Meningkat \\
\hline 2. & Rata-Rata & 69,14 & 75,86 & Meningkat \\
\hline 3. & Daya Serap & $69,14 \%$ & $75,86 \%$ & Meningkat \\
\hline 4. & Ketuntasan Klasikal & $51,72 \%$ & $79,31 \%$ & Meningkat \\
\hline 5. & Nilai Tertinggi & 85 & 90 & Meningkat \\
\hline 6. & Nilai Terendah & 55 & 55 & Tetap \\
\hline
\end{tabular}


Untuk lebih memperjelas perbandingan hasil belajar menulis cerpen siswa kelas IX-B SMP Negeri 3 Selat semester I tahun pelajaran 2018/2019, juga disajikan dalam bentuk grafik perbandingan hasil belajar pada siklus I dan siklus II, seperti pada grafik berikut ini.

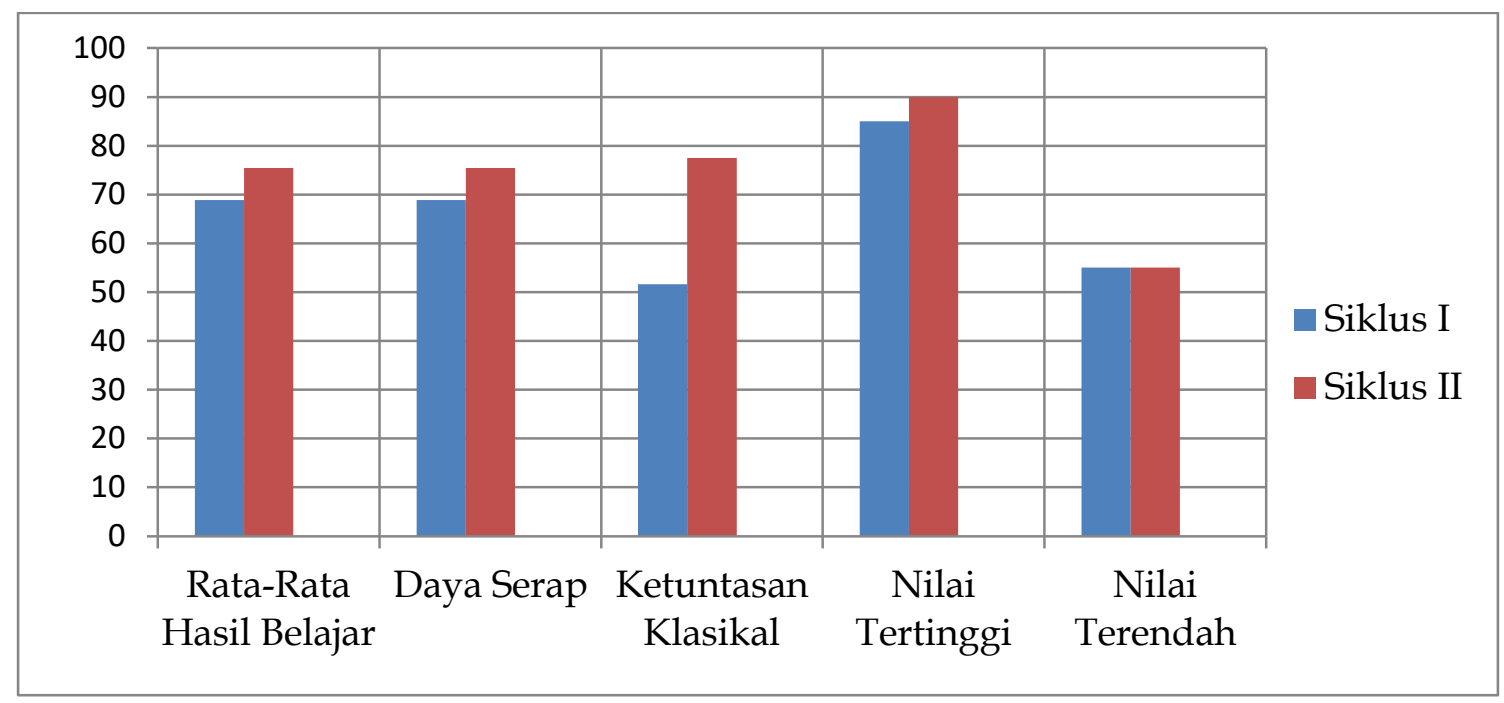

Gambar 3 Geafik Perbandingan Hasil Belajar Siswa Kelas IX-B SMP Negeri 3 Selat Semester I Tahun Pelajaran 2018/2019 pada Siklus I dan Siklus II

\section{Pembahasan}

Bahwa menulis adalah aktivitas seluruh otak yang menggunakan belahan otak kanan (emosional) dan belahan otak kiri (logika) dan tak satu pun belahan otak itu bekerja secara sempurna tanpa adanya rangsangan atau dorongan dari bagian yang lain (De Porter, 1999). Serta dengan penerapan metode Sugesti-Imajinasi membuat para siswa santai (tidak tegang), yang memungkinkan mereka membuka hati mereka secara sadar untuk belajar (bahasa) dengan nyaman dan tidak tertekan (Haryadi, 2010). Hal ini terlihat dari siklus I terdapat 1 orang memperoleh kategori minat sangat tinggi dengan persentase 3,22\%, 15 orang memperoleh kategori minat tinggi dengan persentase 48,39\%, dan 15 orang memperoleh kategori minat sedang, dengan persentase 48,39\%, sedangkan pada siklus II, terdapat 21 orang memperoleh kategori minat sangat tinggi dengan persentase $67,74 \%$ dan 8 orang memperoleh kategori minat tinggi dengan persentase 25,81\%, 2 orang memproleh kategori minat sedang, dengan persentase 6,45\%. Serta, tidak ada lagi siswa yang memproleh kategori minat rendah.

Hasil belajar menulis cerpen siswa IX-B SMP Negeri 3 Selat semester I tahun pelajaran 2018/2019 juga meningkat. Rata-rata hasil belajar siswa pada siklus I sebesar 68,87 yang kemudian meningkat menjadi 75,48 pada siklus II atau terjadi peningkatan 
sebesar 6,61 poin. Daya serap siswa juga mengalami peningkatan, yaitu pada siklus I daya serap sebesar $68,87 \%$ meningkat pada siklus II, menjadi 75,48\%. Secara klasikal pada siklus I dengan ketuntasan individual 16 orang dan, memperoleh ketuntasan klasikal 51,61\%, dan pada siklus II dengan ketuntasan individual 24 orang, dan memperoleh ketuntasan klasikal 77,42\%.

Penggunaan metode Sugesti-Imajinasi dapat mengoptimalkan kerja belahan otak kanan sehingga para siswa dapat mengembangkan imajinasinya secara leluasa. Efek positif dari optimalisasi kerja belahan otak kanan adalah rangsangan atau dorongan bagi kerja belahan otak kiri sehingga pada saat yang bersamaan para siswa juga dapat mengembangkan logikanya. Keseimbangan kinerja otak kanan dan kiri ini diharapkan dapat meningkatkan kemampuan siswa dalam perolehan inspirasi, pengorganisasian inspirasi, pembuatan kerangka inspirasi, dan akhirnya menuliskan inspirasi tersebut dalam bentuk cerpen yang baik.

Berdasarkan analisis data yang sudah disajikan, hipotesis penelitian yang diajukan terbukti bahwa: 1) Penerapan metode pembelajaran Sugesti-Imajinasi dapat meningkatkan minat belajar menulis cerpen siswa kelas IX-B SMP Negeri 3 Selat semester I tahun pelajaran 2018/2019. Hal ini disebabkan karena penggunaan metode SugestiImajinasi dapat mengoptimalkan kerja belahan otak kanan sehingga para siswa dapat mengembangkan imajinasinya secara leluasa. Efek positif dari optimalisasi kerja belahan otak kanan adalah rangsangan atau dorongan bagi kerja belahan otak kiri sehingga pada saat yang bersamaan para siswa juga dapat mengembangkan logikanya.

Keseimbangan kinerja otak kanan dan kiri ini diharapkan dapat meningkatkan kemampuan siswa dalam perolehan inspirasi, pengorganisasian inspirasi, pembuatan kerangka inspirasi, dan akhirnya menuliskan inspirasi tersebut dalam bentuk cerpen yang baik. Tujuan dari metode ini adalah untuk membuat para siswa santai (tidak tegang), yang memungkinkan mereka membuka hati mereka secara sadar untuk belajar (bahasa) dengan nyaman dan tidak tertekan (Haryadi, 2010). Sejalan dengan penelitian yang pernah dilakukan oleh Marisini yang hasilnya dipaparkan dalam bentuk laporan penelitian tindakan kelas (PTK) judul “Upaya Meningkatkan Kemampuan Menulis Cerita dengan Metode Sugesti Imajinasi Melalui Media Pergelaran Wayang pada Siswa Kelas IX A SMP Negeri 6 Semarang (Marsini, 2019). PTK tidak diterbitkan. Semarang".

Penelitian Marsini membuktikan bahwa pembelajaran menulis cerita dengan metode Sugesti-Imajinasi melalui media pergelaran wayang mampu meningkatkan 
minat menulis cerita pada siswa kelas IX A SMPN 6 Semarang (Marsini, 2019). Hal itu terlihat dari hasil nontes pada siklus I dan siklus II diperoleh bahwa sebagian besar siswa senang dan tertarik dengan media pergelaran wayang tersebut. 2) Penerapan metode pembelajaran Sugesti-Imajinasi dapat meningkatkan hasil belajar menulis cerpen siswa kelas IX-B SMP Negeri 3 Selat semester I tahun pelajaran 2018/2019. Hal itu disebabkan karena metode Sugesti-Imajinasi adalah metode pembelajaran menulis dengan cara memberikan sugesti untuk merangsang imajinasi siswa. Dalam hal ini, duduk rileks dengan mata terpejam digunakan sebagai pencipta suasana sugestif, stimulus, dan sekaligus menjadi jembatan bagi siswa untuk membayangkan atau menciptakan gambaran dan kejadian berkesan yang pernah dialami.

Respons yang diharapkan muncul dari para siswa berupa kemampuan melihat gambaran-gambaran kejadian tersebut dengan imajinasi-imajinasi dan logika yang dimiliki lalu mengungkapkan kembali dengan menggunakan simbol-simbol verbal (Haryadi, 2010). Sejalan juga dengan hasil penelitian yang dilakukan oleh Petrus Trimantara (2005) yang hasilnya dipaparkan dalam Jurnal Pendidikan Penabur (No.05/ Th.IV / Desember 2005) judul “Metode Sugesti-Imajinasi dalam Pembelajaran Menulis dengan Media Lagu", membuktikan bahwa pembelajaran menulis menulis deskripsi dengan metode Sugesti-Imajinasi melalui media lagu dapat meningkatkan keberhasilan pembelajaran pada siswa kelas X SMAK 2 BPK Penabur Bandung. Elemen-elemen keterampilan berbahasa yang mengalami peningkatan cukup signifikan adalah (1) penguasaan kosakata, (2) pemahaman konsep-konsep dan teknik menulis, (3) keterampilan menggali pengalaman hidup atau mengingat kembali fakta-fakta yang pernah mereka temui, mengorganisasikannya, dan memberikan tanggapan dalam bentuk simbol-simbol verbal, dan (4) kemampuan membuat variasi kalimat.

\section{Kesimpulan}

Berdasarkan hasil analisis data, dapat disimpulkan sebagai berikut. 1) Penerapan Metode Sugesti-Imajinasi dalam pembelajaran, menulis cerpen dapat meningkatkan minat belajar siswa kelas IX-B SMP Negeri 3 Selat semester I tahun pelajaran 2018/2019. Simpulan ini didukung oleh bukti-bukti emperis yang dinyatakan oleh adanya peningkatan minat siswa. Hal ini terlihat pada siklus I rata-rata minat belajar siswa sebesar 65,16; dengan ketuntasan klasikal 51,61\%; meningkat menjadi rata-rata minat belajar siswa sebesar 83,55; dengan tingkat ketuntasan klasikal 93,55\% pada siklus 
II. Pada siklus I terdapat 1 orang berada pada kategori minat sangat tinggi dengan persentase 3,22\%; 15 orang siswa berada pada kategori minat tinggi dengan persentase 48,39\%; dan 15 orang berada pada kategori minat sedang dengan persentase 48,39\%. Sedangkan pada siklus II, terdapat 21 orang berada pada kategori minat sangat tinggi dengan persentase $67,74 \%$, dan; 8 orang berada pada kategori minat tinggi dengan persentase $25,81 \%$. Siswa dengan kategori minat sedang 2 orang dengan persentase $6,45 \%$; sedangkan siswa yang berada pada kategori minat rendah tidak ada, atau dengan persentase $0.00 \%$. 2) Penerapan Metode Sugesti-Imajinasi dalam pembelajaran menulis cerpen dapat meningkatkan hasil belajar menulis cerpen siswa kelas IX-B SMP Negeri 3 Selat pada semester I tahun pelajaran 2018/2019. Simpulan ini didukung oleh bukti-bukti emperis yang dinyatakan oleh adanya peningkatan nilai rata-rata siswa dari 68,87 ; daya serap $68,87 \%$, dan; ketuntasan klasikal 51,61\% pada siklus I, menjadi nilai rata-rata siswa 75,48; daya serap 75,48\%; dengan ketuntasan klasikal 77,48\% pada siklus II. Berdasarkan simpulan di atas disarankan; 1) Siswa dapat memanfaatkan metode pembelajaran SugestiImajinasi untuk meningkatkan minat dan hasil belajarnya, khususnya pada menulis cerpen. 2) Guru yang ingin menerapkan metode pembelajaran Sugesti-Imajinasi agar mencermati kelemahan-kelemahan ataupun kekurangan-kekurangan yang ditemukan pada penelitian ini sehingga pada penerapan berikutnya memberikan hasil yang lebih optimal dan bardaya guna. 3) Hasil penelitian ini diharapkan dapat digunakan sebagai bahan pertimbangan dalam mengembangkan metode pembelajaran khususnya dalam pembelajaran bahasa. 4) Peneliti lain agar mencoba menerapkan pada pembelajaran dengan materi yang lain, bahkan juga pada pembelajaran mata pelajaran yang lain.

\section{Daftar Pustaka}

Burhan, N. (2011). Penilaian dalam Pengajaran Bahasa dan Sastra. Yogyakarta: BPFE.

Crow, L. . \& A. C. (1989). Psycology Pendidikan. In Educational Psycology. Yogyakarta: Nurcahya.

De Porter, B. and M. H. (1999). Quantum learning: Unleashing the genius in you, atau Quantum learning. In Membiasakan belajar nyaman dan menyenangkan. Bandung: Kaifa.

Depdiknas. (2008). Kamus Besar Bahasa Indonesia Pusat Bahasa. Jakarta: PT Gramedia Pustaka Utama.

Haryadi. (2010). Model Pembelajaran. Semarang: Uness. 
Marsini. (2019). Upaya Meningkatkan Kemampuan Menulis Cerita dengan Metode Sugesti Imajinasi Melalui Media Pergelaran Wayang pada Siswa Kelas IX A SMP Negeri 6 Semarang.

Trimantara, P. (2005). Metode Sugesti-Imajinasi dalam Pembelajaran Menulis dengan Media Lagu. Jurnal Pendidikan.

Wayan Nurkancana, S. (1992). Evaluasi Hasil Belajar. Surabaya: Usaha Nasional.

Wardani, IGAK. 1981. Pengajaran Sastra. Makalah disajikan dalam Lokakarya di Malang Tahap ke- 2 Proyek Pengembangan Guru, Malang, 12 Juli.

Wulandari, Gusti Ayu Putu Trisna. 2007. “Penerapan Teknik Tanya Jawab untuk Meningkatkan Kemampuan Menulis Eksposisi Siswa Kelas X SMA Negeri 2Gerokgak". Skripsi (tidak diterbitkan). Jurusan PBSID, FBS, Undiksha.

Yonny, Acep, dkk. 2010. Menyusun Penelitian Tindakan Kelas. Yogyakarta: Familia. 